\title{
Banking Liquidity in Morocco
}

\author{
Mouhtadi Aouatif \\ PhD student-Department of Economics and Management, Center of Doctoral Studies, Faculty of Economic \\ Sciences, University Mohammed V-Souissi, Rabat, Morocco
}

\begin{abstract}
The latest financial crisis that shook the world and its effects continue to worsen, especially the successive failures of major international banks (Lehman Brothers in the United States for example) have returned to the center stage the issue of banking risks including liquidity risk. This risk must be currently managed by more sophisticated methods. The central purpose of this research is the analysis of the liquidity of Moroccan banking sector, because ultimately all proposed routes are articulated around it. Thus, monetary policy tends to naturally control the increase in the volume of money and quasi-money supply available to the agents of non-banking sector to make it compatible with the rate of change of the aggregate supply of goods and services, that is to say, the gross domestic product.

This article provides evidence, based on a retrospective analysis of the various underlying causes of under bank liquidity
\end{abstract}

Key words: Morocco, Banking Liquidity, Money market, crisis of liquidity

\section{Introduction}

During the last decade, rapid innovation in financial markets and the internationalization of financial flows have almost changed the banking landscape giving rise to new financial instruments and more diverse and complex activities simultaneously. Technological progress and deregulation have created new opportunities for banks, and at the same time a stronger competitive pressure has increased the possibilities of contagion.

The evolution of banking systems and markets have also led to significant problems for monetary policy and showed significant needs regarding prudential measures in macroeconomic policy. In the context of volatile and diverse competitive markets, apart from management and effective supervision - that are necessary to the security of banking institutions and the stability of systems factors- provide an adequate macroeconomic policy and sustainable, consistent and well-developed legal framework. However, concerning an "excessive" procyclicality in the financial system, in turn, highlighted the need to take action in the areas of prudential regulation, accounting, risk measurement or monetary policy in order to strengthen the financial system and macroeconomic stability.

In this evolutionary perspective, the Moroccan banking system has undergone profound changes that are a little bit dramatic but with multiple consequences. These changes were made to adapt the regulatory arsenal to the national economy and international standards changes, requiring a redesign of the institutional framework, in order to increase the efficiency of supervision and control. For this purpose, amendments were introduced in the Banking Act, while a greater autonomy of the Central Bank has been dedicated in the reform of its statutes.

The monetary system has an important role, liaising between monetary liquidity in the economy, the international banking system liquidity and domestic liquidity in the banking sector. Indeed, monetary liquidity in the economy returns to bring changes in the money supply and the gross domestic product.. This shows the existence of reciprocal connections between the monetary sphere and the real sphere of the economy that requires a level of optimum balance, that is to say an economy without excessive inflationary or deflationary pressures. However, the degree of monetary liquidity in the economy is directly influenced by the state of liquidity in the banking sector in complex relationships.

Having these principles like objective, this article is devoted primarily to a specific field where macroeconomic stability and financial stability are agreed: the banking liquidity. A retrospective analysis going from 1997 to 2012 is developed in this study in order to explain the causes under unclaimed problems of the liquidity in Morocco.

\section{Banking Liquidity and Market Liquidity}

The study of the liquidity banking theory is present in the majority of the handbooks and monetary works but curiously, it is generally considered under very particular aspects. One meets initially descriptions of the institutions of the money market, variables according to the countries, sometimes within a purely national framework, sometimes from a comparative point of view according to the countries. One describes the various 
processes of recourse of the banks to the money market, the intermediaries which operate on this market, the modes of intervention of Central Bank and the evolution of this market since decades. There are also the reports and the official reports which provide to a certain number of statistical data correspondent to stations whose precise definition remains in certain cases a complete mystery, and who are already synthesized.

Nowadays, the liquidity crises don't only concern the depositors and the banks, but rather in the interbank transactions on the financial markets. They correspond to a degradation of the conditions of exchange of liquidity among financial institutions, whose tensions on the interbank rates are the revealing factors.

However the most relevant definition of the banking liquidity is "the capacity of a banking institution to face its obligations of treasury according to their expiry" and one can define it in two different ways. A narrow definition retained by the banking literature also called "liquidity of financing". This concept recovers the liquidity (i.e. species or credits likely to be converted quickly in cash and held for this purpose) necessary to satisfy the requests for withdrawals of short-term funds emanating from the counterparts or to cover their operations. This dimension of the liquidity is probably prevalent within the framework of the processing and manufacture such as it is traditionally practiced by the banks. The second definition, broader, considers that the banks are also implied in the negotiation of credits. This second dimension, nearer to the "liquidity of market", milked with the capacity of the banks to liquidate a nonmonetary credit.

Analogies between market liquidity and liquidity of banks were highlighted by Borio (2004), "the genesis of a market crisis is quite similar to that of a banking crisis." For monetary and financial stability, it seems useful to understand the collective behavior of market participants and the interdependencies between different financial institutions and market dynamics (Davis, 1994)

The financial crisis of 2008 put in revealed the importance of the liquidity in the banking environment. It showed that the constraints of the stockholders' equity are alone insufficient to avoid the banking bankruptcies. They must be accompanied by constraints on the liquidities. The abundance of liquidity had led the supervisors and the banks to neglect its risk. The banks had largely evacuated the risk of liquidity of their stress-tests. In this direction, several institutions of international regulations (in particular committee of Basle) attached an importance to the reinforcement of the stockholders' equity of the banks to the detriment of the liquidity of the banks and which aims to improve the risk management within the establishments and to better do to correspond lawful equities to the risks really incurred by these last.

\section{Diagnosis Of The Liquidity In Morocco 1997 - 2012:}

Each one of these relations between general liquidity of the banking economy-liquidity, liquidity banking-liquidity external of Central Bank, and liquidity external general-liquidity, plays in the two directions. In fact, each first term couple is determined by the second. The reciprocal one is also checked: the general liquidity of the economy determines the banking liquidity according to the intensity of the end-users application for credit, the liquidity of the banks influences the liquidity external of Central Bank because the banks can convert the dirham, under certain conditions, to currencies with the detriment of the official reserves, to invest abroad; finally the general liquidity of the economy determines on the whole the external liquidity of Central Bank since inflationary tensions cause under certain conditions of the exits of currencies, and reciprocally in the event of surplus.

Actually, economists are far from unanimous on the existence of these connections and the direction in which they play and especially the mechanisms they contain. Indeed, the connection between the general liquidity of the economy and the external liquidity of Central Bank cause a controversy on the assumption of a balance of payments surplus for example, the entries of currencies cause an increased creation of credit, and reveal or develop inflationary tensions in the economy, i.e. an increase in the general degree of monetary liquidity. The partisans of the theory of the compensation answer by stressing that the entries of currencies increase the liquidity of the banks and not their deposits and that those benefit from it to reduce their debts towards Central Bank, without to increase their credit to the economy money supplies; the monetary degree of liquidity of this one remains unchanged.

However, in connection with the interdependence between external liquidity of Central Bank and internal banking liquidity: one can advance that the placements abroad banks in currencies are directly responsible for the growth of the operations of injections of liquidity by Bank Al-Maghrib which constitute one of the ways by which the banks are involved in debt at Central Bank. But, it is easy to state that the variations of monetary reserves of Central Bank are only one of the factors of the banking liquidity, in the same way, the banks debt by open-market is only one from another means by which the banks can reconstitute their treasuries while they are indebted.

The operations of the banks with the public, the Treasury and the foreigner exert for the majority of them an incidence on the amount of the reserves in currency central bank which the banks hold or likely to acquire. It is in the plan of the communications between the monetary circuits those of the manual currency, of the currency of the Treasury and of the foreign currencies that certain operations feed or on the contrary restrict the reserves of the banks in liquidity. These movements are only undergone by the banks, which do not lay out 
that very few means to influence the end users in their choice of the forms of detention of box, or the Treasury in its choices of such or such form of currency to regulate its expenditure or to box its receipts, or finally, operators of the international business or all the agents which wish to carry out conversions of foreign currencies.

Thus, the banking liquidity is influenced by autonomous factors of: the favorite rate of the public for the manual currency; the situation of public finances; and the state of the balance of payments. Important requests for tickets on behalf of the public; a reduction in the expenditure of the Treasury; exits of currencies resulting from a balance of payments deficit oblige the banks to carry out payments in currency central bank to get tickets or currencies or to regulate with the Treasury the accounts - checks and the transfers drawn by the debtors from the Treasury. Each time, the accounts in currency central bank of the banks is affected, and their liquidities decrease, i.e. their capacities to finance appropriations with the economy and to carry out a profit.

The banks are brought to reconstitute their treasuries in currency central bank by seeking surplus reserves offered by institutions better equipped in means with treasury or, in last spring; when these contests are insufficient; by yielding financial credits to Bank Al-Maghrib or to borrow the liquidities which are lacking.

In Morocco, this evolution of the liquidity is exogenous and marked by an exceptional increase in the assets external Nets due in particular to the depreciation of the dirham compared to the euro following the revision of the basket of exchange (80\% Euros and 20\% Dollars) source, the debt reduction of the Treasury on the domestic market which results in injections of liquidity in the monetary circuit, in continuation, the regular effect of the transfers of the Moroccans residing abroad and of the receipts of voyage which came to improve the situation of the assets external and thus of the liquidity of the banking system. In the same way, we attended a chronology of the successive shocks of the liquidity due in particular to the important surges of currencies, most significant are the following:

\section{August 1999}

- Re-entries of currencies related to the product of second license GSM;

- Situation aggravated by the behavior of the money market Treasury (Treasury debt reduction). In 2001

- Significant increase in the banking liquidity in relation to an surge of foreign assets because of the opening of the capital of Ittissalat Al Maghrib in February 2000;

- Raise transfers of the MRE of 60,5\% in 2001 passing from 22 billion dirhams to 36 billion dirhams. In 2002

- Excess liquidity because of a substantial reinforcement of the external assets, in March 2002.

- In 2003-2007

- The money market was marked by surpluses of liquidity, an exceptional situation which persisted until 2007 and was the result of a succession of privatization operations (the transfer of $80 \%$ of the capital of the Control of the Tobaccos), of a strong appreciation of the transfers of the Moroccans resident abroad (MRE) and expansive effect of the tourist activities.

\section{Graphe1: Evolution of the need/surplus for liquidity of the banks}

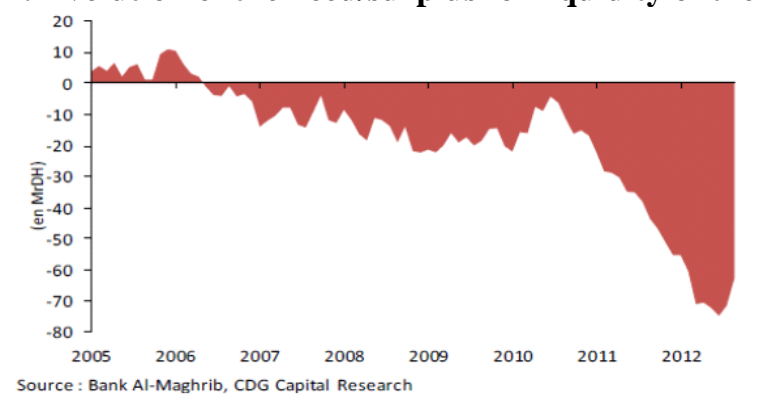

From 2007

- The Moroccan money market plunges in a state of under-liquidity. Several factors contributed to this situation, on the one hand the blaze of the courses of the raw materials, the release of the international crisis which has affected the foreign exchange revenues and on the other hand the high rate/rhythm of distribution of the appropriations, in particular compared to the collection of the deposits. 


\section{Graph 2: Evolutions of the external assets Nets in millions of dirhams}

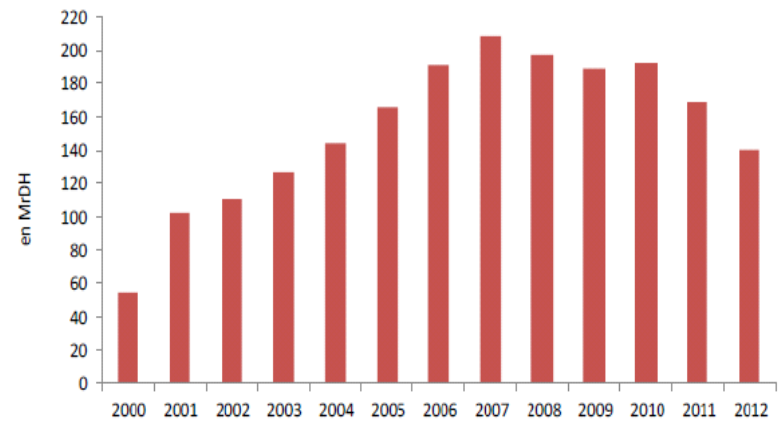

Source : Bank Al-Maghrib, CDG Capital Research

Also let us note that within the framework of the process of financial liberalization, the behavior of the banks played in the direction of an improvement of the banking liquidity. On the one hand, the excess liquidity comes partly from banking management itself, and this in spite of the financial liberalization which resulted in the liberalization of interest rates, the lifting of the credit rationing, the suppression of obligatory employment... etc and which should result in an increase in appropriations. The banks devoted a good portion of their resources to the placements in goods of Treasure. This choice of short term, profitable for the banks and without risk on the financial plan, however presents the disadvantage of generating modifications of the structures of financing and structure of the assessments of the banks.

\section{Subjacent Causes Of Under Banking Liquidity}

The recent world-wide crisis put a term at a cycle of favorable economic conjuncture, starting at the beginning of the decade, and in which the majority of the industrialized countries and emergent carried out the growth rates significant and contributed to the development of the international commercial exchanges.

Morocco, emergent economy, were naturally exposed with the misdeeds of the economic crisis in 2009, namely the contraction of the overseas investments, the thinning down of the transfers of Moroccans resident abroad, the fall of the commercial exchanges but also the retreat of the incomes coming from activities set up as priority sectors of development for the government, namely tourism as well as Offshoring.

It should be noted that the banking lack of liquidity is one of the consequences of the international financial crisis on the Moroccan economy; exit of the capital not covered by consequent entries.

In this logic, there exist several factors of contagion by which the Moroccan economy is correlated with the repercussions of the aforesaid the crisis.

Destruction of the currency for the acquisition of foreign currencies: the decrease in the demand of the foreign countries involved a fall of Moroccan exports bound for these markets, which dug the deficit of the trade balance what wants to say; Morocco imports more than it exports what is normal. Thus Morocco was obliged to destroy part of its currency to buy currencies in order to make up this deficit of the trade balance which continues to grow hollow.

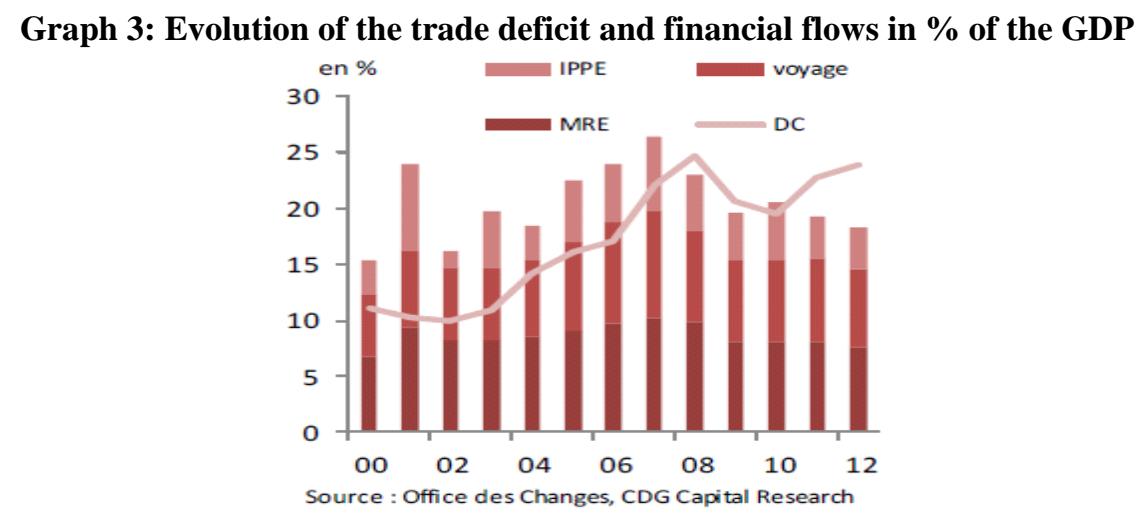

Transfers of the Moroccans resident abroad: the fall of the activity of the principal or applicant for work foreign labor sectors seasonal, in particular agriculture and Buildings and Public Works, touched full whip the 
incomes of the MRE, which limited the transfers of money bound for Morocco. This was negatively reflected on the household consumption and the development of the real estate market and the consumer goods.

Flows of foreign assets: The crisis reduced the attractiveness of the area in terms of collecting of the private capital, because of the world economic deceleration but also of the arbitration opportunities which can henceforth offer of other destinations in the world. Also, launchings of the various investment plans were delayed or given up fault of financing.

Payment of the dividends by the companies with their foreign shareholders: The exit of the dividends is another element that becomes heavy on the external accounts. The overseas investments carried out within the framework of the intense vagueness of privatizations weigh considerably on the external accounts, from the importance of the money exits which they cause. As example, in 2011, the exits (dividends repatriated by the companies with dimensions and not - dimensioned) reached nearly 20 billion dirhams, against 15 billion in 2010 and 9 billion in 2008. During the international crisis, a good part of these investors in lack of liquidity pumped in an exceptional way in the cases of the Moroccan companies to cash finance their business elsewhere (Maroc Telecom and Vivendi, Arcellor Mittal and Sonasid...). With final, the aggravation of the external deficits heavily impacted the level of the reserves these last years. Moreover in 2012, the assets external to Morocco reached 140 Millions dirhams about 4 months of importation. Let us recall that in 2006, these reserves represented a little more than 9 months of imports.

Graph 4: Evolution of the transfers of the funds of the MRE in million DH

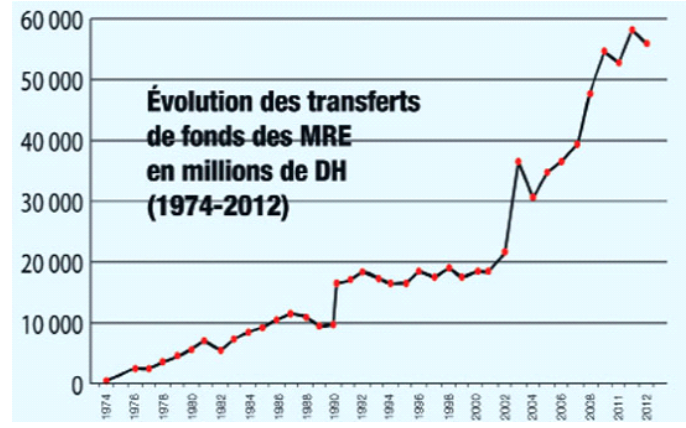

Tourist receipts: the reduction in the tourist receipts of 9,5\% finding its justification in the fall of the incomes of households in the transmitting countries tourists limits the potential of consumption and investment of the latter. To that are added the various arbitrations in terms of price and quality of tourist offer on behalf of the households in times of crisis. Indeed, the fall of the real prices in the European tourist areas (Spain, the United Kingdom) reduced competitive Moroccan destinations.

\section{The insufficiency of the mobilized saving:}

Monetary and the credit policy adopted by Morocco provoked a quantitative discouragement of institutional and private savings, and thereafter a structural deficit in resources. Indeed, mobilization of savings banks is currently less developed compared to that observed in developed mainly because of the existing crisis economies. But the potential for improving the savings likely to be collected by banks is extremely important. Moroccan banks are also not always motivated or forced to implement a wide range of interest rates (mixed fixed, variable ...) due to weak competition. At this level, a large dynamic competition that is expected not only will improve the conditions for mobilizing savings but at the same time facilitating access to bank credit for the vast majority of companies that can offer viable operating accounts. The question that arises is how to develop a long-term savings that can provide the foundation for accelerated and sustainable growth of bank reserves in terms of liquidity. 


\section{Conclusion}

The use of the traditional tools by our banking system to cover itself against the risks of liquidity makes this risk more delicate to evaluate. In front of this situation, this article tries to develop an analysis of the banking liquidity in Morocco through the chronological evolution and especially, when the control of this type of risk currently became, on the international plan, one of the strategic axes in the management of the bank. We currently have a description of the various unclaimed penny causes of under banking liquidity of which the repercussions are likely to amply improve our comprehension of the processes and mechanisms monetary relating to the Moroccan banking system.

One can conclude that the Moroccan banking system profits from a lawful and operational infrastructure in conformity with the international standards more sophisticated much and concentrated. It is certainly characterized by a competition, courteous, but keen which explains the performance and the profitability of the Moroccan banks that it is in the activities of market or retail banking.

Thus, one can conclude that the fluctuation of the banking liquidity is of exogenic nature, the width is reinforced more and more by a massive surge of the monetary transfers of the Moroccans residing abroad and the capacity limited of the Moroccan economy to absorb the surplus liquidities.

\section{Bibliography}

[1]. Allen (F.) and Scale (D.) (2005), "From cash-in-tea market pricing to financial fragility", Newspaper off the European Economic Association, vol. 3, exit 2-3, p. 535-546

[2]. BASEL COMMITTEE ONE BANKING SUPERVISION (2000), "Sound Pratices for Managing Liquidity in Banking Organizations", February.

[3]. Borio (C.) (2004) "Market distress and vanishing liquidity: anatomy and policy options", (A) Working Papers, $\mathrm{n}^{\circ} 158$

[4]. DEMEY P., A. FRACHOT and G. RIBOULET (2003), "Introduction to banking management credit-liability “, Economica.

[5]. Goodfriend (Mr.) and King (R.A.) (1988), "central Financial deregulation, monetary policy and banking", in Haraf (W.S.) and Kushmeider (R.M.) (eds.), Federal Reserve Bank off Richmond, Economic Review, 3 May 22nd, th and th /juin

[6]. Goodhart (A.C.E.) (1995), "Central The Bank and the financial system”, Cambridge, MY: MIT Near

[7]. Saunders (A.) (1987), "international The interbank market, contagion effects and financial crises", in

[8]. Doors (R.) and Swoboda (A.) (eds.), "international Threats to financial stability", Cambridge, Cambridge University Near

[9]. STRAHAN P. (2008), "Liquidity Production in 21st Century Banking", Working Paper nº 13978, NBER

\section{Webography}

[10]. www.bkam.ma

[11]. www.finances.gov.ma/

[12]. www.standardandpoors.com

[13]. www.creditmetrics.com

[14]. www.ccg.ma

[15]. www.ssm.com

[16]. www.aecm.be

[17]. www.perspective.usherbrooke.ca

[18]. www.ifs.du.edu/

[19]. www.imf.org/ 